\title{
Optimizing the system of placing Orthodox parish church complexes in modern urban environment of Saint Petersburg
}

\author{
Lydia Kondratieva $^{1, *}$, Maria Ivina $^{1}$, and Rashid Mangushev ${ }^{1}$ \\ ${ }^{1}$ State University of Architecture and Civil Engineering, 190005, St. Petersburg, Russia
}

\begin{abstract}
The present paper discusses some solutions for optimization of the system of placing Orthodox parish church complexes (PCC) taking into account the traditions of temple architecture, current conditions and strategy of urban and socioeconomic development of Saint Petersburg. The urgency of this topic is substantiated by the construction of churches currently proceeding in Saint Petersburg. However, there is a problem of advancing the existing typology of parish complexes and enhancing the system of their placement on recently developed lands, taking into account modern environment of Saint Petersburg. The paper considers townplanning problems of the existing system of PCCs in Saint Petersburg. In order to work out some solutions for integrating various types of PCCs into the city structure, certain assessment criteria for territories of Saint Petersburg were determined. Recommendations for each type of PCCs were made, concerning the territorial placement in the city structure, possible space-planning solutions, territorial accessibility, elaboration of a site plan of a church yard.
\end{abstract}

\section{Introduction}

The present study is aimed to develop scientifically sound solutions for optimizing the system of placing Orthodox parish church complexes (hereinafter PCCs) in Saint Petersburg's modern urban environment.

The study urges to assess the role of parish churches in the elaboration of urban and socioeconomic plans of the city, formation of the architectural and artistic image of Saint Petersburg. The paper identifies the reasons for the spontaneous development of church architecture and makes suggestions for further effective regulation of the process of creating the system of PCCs in Saint Petersburg.

Suggestions for optimizing the system of placing Orthodox parish church complexes are made taking into account the traditions of temple architecture, modern conditions and the strategy of urban planning and socio-economic development of Saint Petersburg.

The scientific basis of the present study comprised the works of Archimandrite Alexander (Fedorov), Protoiereus Alexander (Bertash), V.A. Nefedov, P. Nikonov, S.V. Sementsov, who have considered problems of development of urban environment, town-

* Corresponding author: kondratjevaln@yandex.ru 
planning aspects of church placement and compositional significance of religious complexes within the structure of a city [1-7].

\section{Materials and methods}

To work out solutions for optimizing the placement of Orthodox parish church complexes in the modern environment of the city, proceedings covering the following problems and issues were used: design and construction of modern Orthodox churches; development of urban environment and town-planning aspects of placing buildings, compositional significance of parish churches in the city structure.

The methodological basis of this research is an integrated approach that involves the analysis and synthesis of literature sources, Internet sources and regulatory documents highlighting the practice of designing and erecting modern PCCs.

\section{Results}

\subsection{Town-planning problems of the PCC system existing in Saint Petersburg}

In Saint Petersburg, current church construction is mainly executed in modern districts. However, in the existing building development, houses of worship were not stipulated in a master plan that was adopted without taking into account the problem under consideration. Churches are erected based on the principle of residual space, so they usually do not acquire proper urban and semantic meaning [1], [6].

Today, PCCs are concentrated in historical districts of the city, while on lands of mass development they are located in random order, mainly in residential areas, without taking into account the needs of worshippers.

The study showed that there is no single urban development concept for placing parish churches in the city, which is manifested through the following aspects:

- there is no connection between a type of a PCC and a functional planning zone of the city;

- the spread of parish churches over the city is not schematized at all: usually one district has excessive amount of churches, while another acutely lacks them;

- when placing churches, the existing transport scheme is not taken into account, so convenient transport accessibility of PCCs is not ensured in most cases;

- Land plots for the placing PCCs are allocated in recreational areas (parks, embankments) or in residential estates (within a residential quarter of a perimeter building development), while in most cases the traditions of placing churches in important urban areas are not taken into account.

It is worth noting that the affordability of placing new churches in bedroom suburbs is limited by the lack of territories required, which does not allow creating a balanced system. However, not all city's potential of developing the PCC system is used, for instance, reserve territories of various purposes.

\section{Suggestions on the typology of PCCs in St. Petersburg}

Based on the results of a comprehensive research in the field of the formation of architectural typology of PCCs, several types of PCCs were proposed and elaborated. Dominance of functional spaces of a complex, composition of its premises and architectural and a space-planning concept are the distinctive features of PCC types [3]. 
It is worth noting that a scope of a complex and worshipers' needs play a crucial role in the development of modern PCCs' architecture.

Proceeding from generalization of the results of domestic and foreign sociological researches, the data from expert polling worshipers and churchmen, the types and features of modern parishes peculiar to Saint Petersburg citizens were determined. The existing types of parishes have diverse semantic demands while visiting churches, different ratios of Orthodox worshipers, numbers of parishioners, formation principles, dominative social activity directions. [3].

Type 1 - Social PCC. The activity of the complex is focused on providing spiritual and psychological aid, which corresponds to the needs of a Conventional parish. The area of liturgical service is dominant there. Such a complex is notable for the presence of an elaborated multifunctional information and exhibition space.

Type 2 (A, B) - Educational PCC can be both an independent object or a one included in a structure of a residential or public multifunctional complex. Religious-and-educational, educational and pedagogic activities prevail in such a PCC, which mainly corresponds to the needs of the Collective parish.

Type 3 - PCC of Spiritual Development of Children and Youth is a large independent object, which requires a space-planning solution including an atrium or a pavilion. Educational and recreational areas dominate in such a complex. Recreational, educational and religious-educational activities prevail at complexes of this type, which satisfies the needs of Collective and Missionary parishes.

Type 4 - PCC designed as an Educational and medical-and-social center is a large independent object, which also requires an atrium or pavilion space-planning solution. These complexes are notable for the dominance of residential, medical and educational areas. Such a complex carries out charitable activities, which satisfies the needs of the Collective parish and the parish of Transcendent Fate.

Type 5-PCC designed as a Social and rehabilitation accommodation center. Such a center is a large independent object, which requires a pavilion space-planning solution. Such a complex usually features by the dominance of household, residential and utility functional areas. Orthodox rehabilitation programs are elaborated in such a PCC, which corresponds to the needs of the parish of Transcendent Fate.

\section{Criteria for assessing the territory of Saint Petersburg for the placement of parish church complexes}

In order to make suggestions on the placement of different types of PCCs in the city structure, criteria for assessing the territory of Saint Petersburg were defined.

The strategy of urban development of Saint Petersburg involves the formation of a polycentric structure, as well as the development and modernization of bedroom suburbs territories, the revitalization of industrial zones [2], [7]. This development direction provides for the appearence of new public centers. PCCs could become such centers of people's cultural life since they possess some cultural and spiritual potential and are able to provide their functions to the city.

An analysis of the functional-planning structure of the city was carried out in order to formulate recommendations on the placement of PCCs.

When moving from the city center down to suburbs, one can observe the changes in housing development types, public spaces, population density and the presence of reserve areas. Territories adjacent to central districts are notable for mid-rise building development and the presence of large empty industrial areas. These days, as far as the city developes, some industrial areas are being removed from the service. Many industrial areas are conveniently connected with transport infrastructure and water bodies and are placed not 
far from historical places of the city [5]. Residential areas with mass building development is characterized by the prevalence of high-rise buildings spread with high densityand by the presence of reserve areas. Territories of suburban settlements are characterized by low-rise buildings and their low density, by the presence of undeveloped territories [4].

Suggestions for optimizing the system of placing PCCs in the city structure are based on the fulfilment of the following conditions:

- interrelation between a type of parish and a church corresponding to it and a functional area of the city;

- interrelation between a type of PCC and a functional area of the city;

- choise of a site in accordance with a functional planning solution of a church; a site, its arrangement, location and size should satisfy the needs of a certain parish;

- location of a PCC should be determined by a point of the best perception, or a complex should be erected at the intersection of the main compositional axes and functional flows; possibility of further development of PCC territory;

- ensuring the territorial accessibility of a PCC (pedestrian or transport).

The existing structure of the city has the presence of territorial reserves for the construction of facilities for various purposes, suburban recreational areas; a large territory and a significant coastline, has a developed system of public passenger transport $[2,7]$.

\section{Suggestions on placing PCC types in the city structure and requirements for the development of a site plan for a PCC}

It should be noted that all parish churches have several general principles of their placing, which are based on traditions or individual and characteristic for a certain type of PCC.

Suggestions for placing PCC types in the city structure are made proceeding from traditions, modern conditions and current stage of completion of Saint Petersburg's master plan (Figure 1) [3]. The following recommendations are given for each type of PCC: on territorial location in the city structure, on options of a spatial solution, on territorial accessibility. Suggestions on elaboration of a site plan of a yard for each PCC type were made (Figure 2) [3].

Type 1 - Social PCCs are proposed to place in areas of social-and-business development, on territories adjacent to both central districts and areas of mass development. A PCC can be solved as an independent object (a space-saving layout is recommended) or be a part of a structure of a public complex (an integrated attached layout). This type of PCC does not provide for a church yard. Convenient connection between PCC and various means of public transport should be ensured.

Type 2A - Educational PCCs are proposed to place in social-and-business areas, on territories adjacent to central districts and areas of mass development. A PCC can be solved in cooperation with educational institutions or a business center. This type of PCCs does not provide for a church yard. Convenient connection between PCC and various means of public transport should be ensured.

Type 2B - Educational PCCs are proposed to place in residential and recreational development areas, on territories adjacent to central districts and areas of mass development. A PCC may be solved as an independent object (a space-saving layout is recommended) or as a part of a residential complex's structure (an integrated attached layout). A PCC can be placed in a park, public garden, in residential development area. This type of PCCs is advidable to provide with a church yard with an area of $0.3-1$ ha. The following functional areas of a yard should be provided: church area, recreation area for adults and children, green area, area for celebrating festivals. It is necessary to ensure pedestrian connectivity of a PCC. 
Type 3 - PCCs of Spiritual Development of Children and Youth are proposed to placr on territories of former industrial areas, in recreational zones. This type of complexes require atrium or pavilion space-planning solutions. The following functional areas should be provided on a church yard: a church area, recreational area for adults and children, green area, area for celebrating festivals, general physical education area, stage, utility area, parking lots. This type of PCCs is advisable to have a church yard with an area of $1-1.5$ ha. Conveniency of both public and private transport connectivity of a PCC should be ensured.

Type 4 - PCC as an Educational and Medical and Social Center is proposed to place on territories of former industrial areas, in the recreational zone. The following functional areas should be provided on a church yard: church area, recreational area for adults and children, green area, area for celebrating festivals, utility area, parking lots. This type of PCCs is advisable to have a church yard with an area of $1-1.5$ ha. Conveniency of both public and private transport connectivity of a PCC should be ensured.

Type 5 - PCC as a Social and Rehabilitation Center of a Settlement is proposed to place in recreational areas of suburban settlements. This type of complex require a pavilion space-planning solution. The following functional areas should be provided on a church yard: church area, recreational area, green area, area for celebrating festivals, utility area, parking lots, farm yard, fruitery, area of field and vegetable crops. This type of PCCs is advisable to have a church yard with an area of 2 to 10 ha. Convenient public and private transport connectivity of a PCC of this type should be ensured.

A churchyard is one of the core town-planning elements for any church complex, since its layout, location and size directly influences the life quality of a parish church. When developing a site plan of a PCC, the following recommendations should be considered: multifunctional organization of PCC's territory; arrangement of objects taking into account functional interconnection of groups of premises; formation of thematic zones; place for celebrations taking into account possibilities of crowd; flow separation; accessibility of all objects for visitors.

Depending on a type of a PCC, the following composition of yard's functional areas is possible: church area (church, space for processions), recreational area for adults and children, green area, area for celebrations, general physical education area, a stage, utility zone, parking lots, farmyard, fruitery, areas of field and vegetable crops. A place for a church complex should be chosen thoroughly, taking into account its accessibility and high attendance, as well as maintaining the balance of the existing territories. 


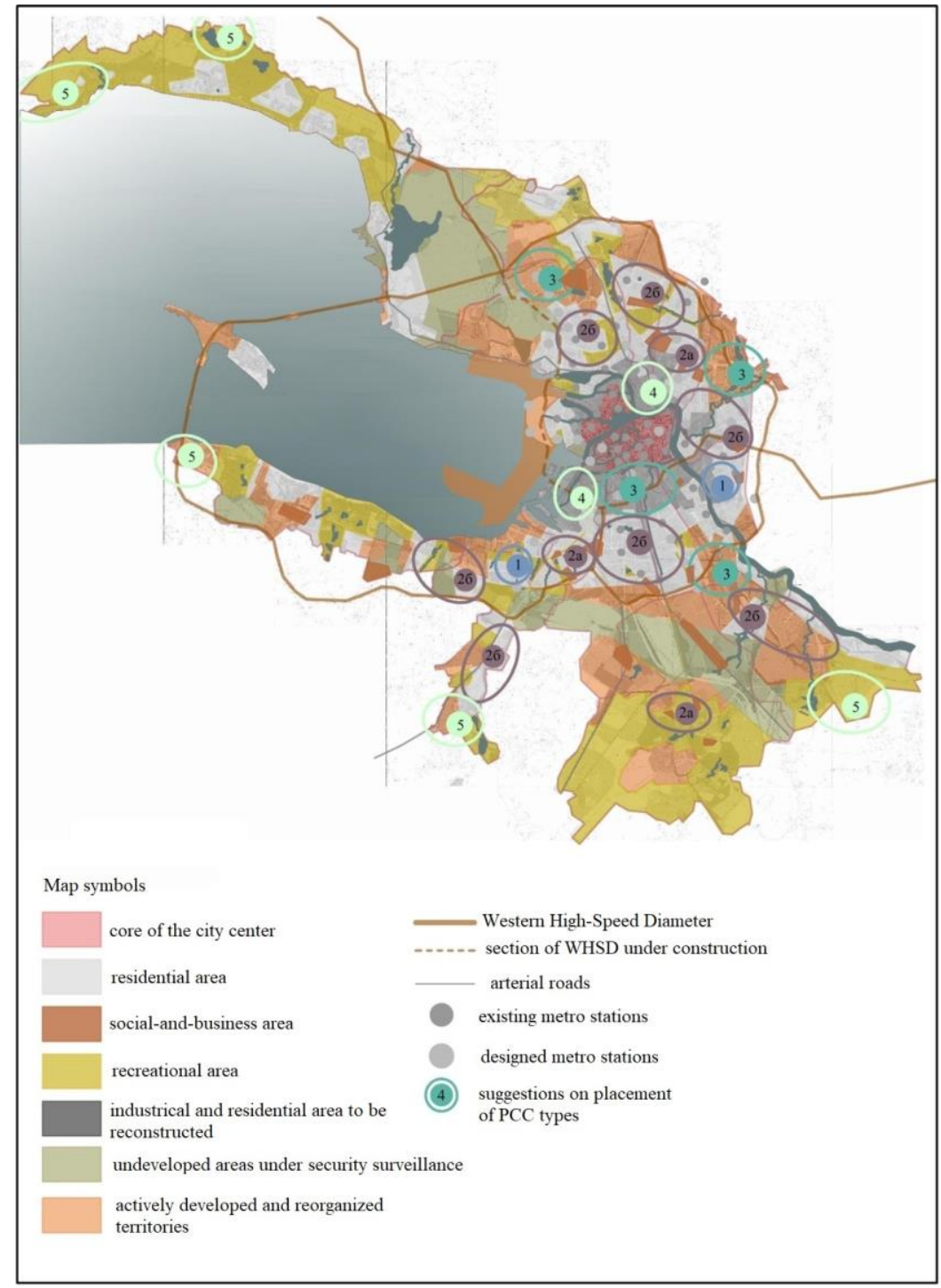

Fig. 1. Recommendations on placing PCCs in the city structure. 


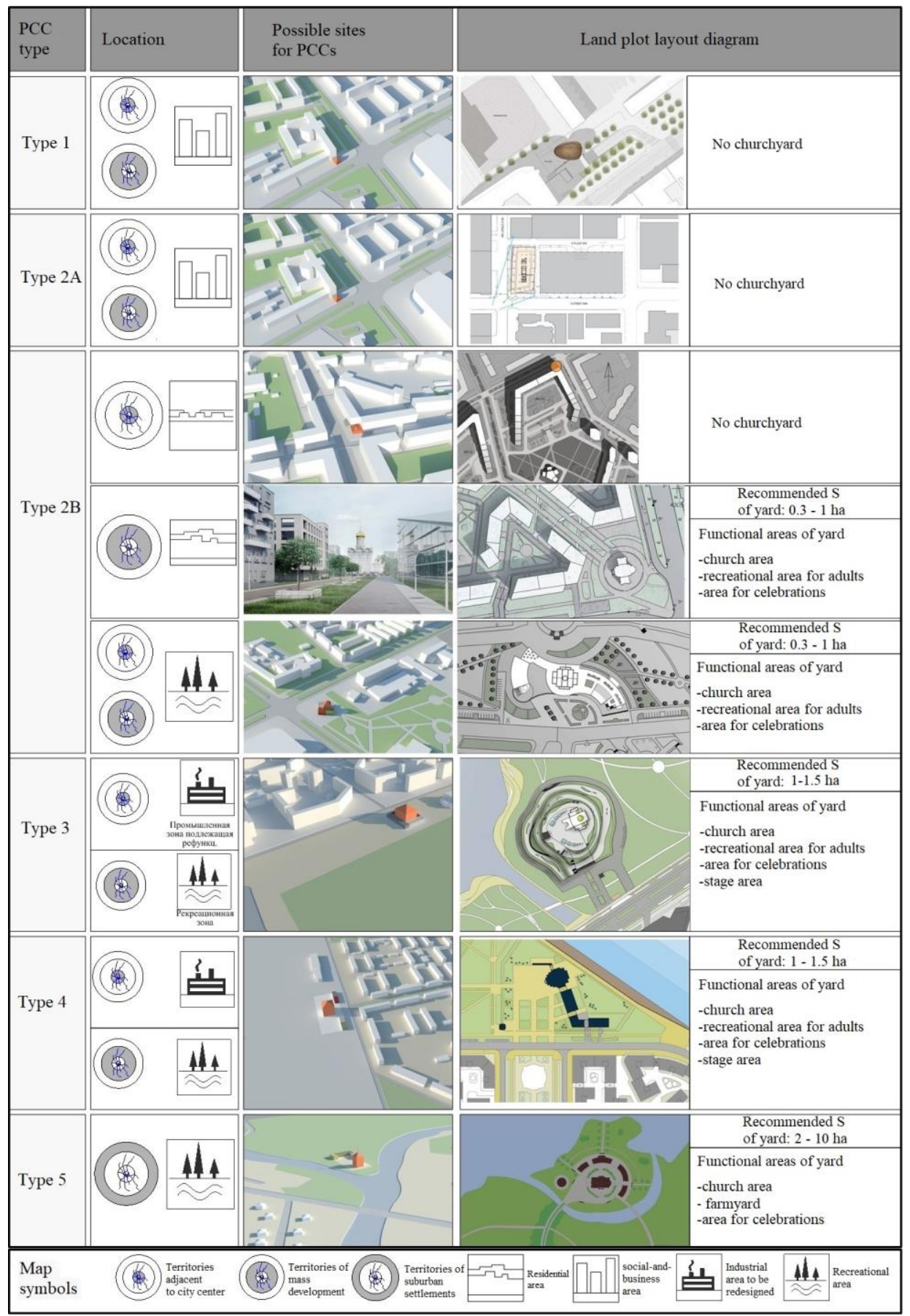

Fig.2. Recommendations on development of a PCC site plan. 


\section{Conclusions}

In conclusion, it is worth noting that Orthodox parish church complexes are an important element for urban and socioeconomic prospects of development of the city. Saint Petersburg's environment has great capabilities for successful optimization of the system of placing Orthodox parish church complexes. In order to bring this plan to life, the following requirements should be taken into account: PCCs should be included in all functional planning structures of the city; PCCs should be placed in areas possessing certain urban importance; convenient walking and transport accessibility should be ensured; further development of a PCC territory should be available.

\section{References}

1. A. Bertash, J.Kap. 1, 6, 8-65 (2019)

2. http://archpeter.ru/arkhiv/2015/01/gradostroitelnoe-razvitie-sankt-peterburga-vramkakh-strategii-2030/

3. M. S. Ivina, J. Sov.probl 1 (2015)

4. P. Nikonov, J.Kap. 1, 26, 20-23 (2016)

5. URL: http://www.ec-group.ru/upload/projects/Strategia_socialnoekonomicheskogo razvitia SantPeterburga_do_2030 goda. Vybor_osnovnyh napravleniy celei.Ver.2.pdf.

6. J. Kormina, S. Luehrmann, J. Am.Acad. Rel., 86, 2, 394-424 (2018)

7. V. Glinskiy, L. Serga, M. Khvan, Proc. CIRP 40, 625-630. (2016) 